\title{
A THOUSAND PAPERS OF JOSIP PEČARIĆ
}

\author{
SANJA VAROŠANEC
}

\begin{abstract}
In the last four decades academician Josip Pečarić has produced an enormous number of scientific papers and books. He has published more than one thousand mathematical papers in scientific journals and books. Furthermore, he is an author of more than 20 mathematical monographs, books and textbooks. Besides the great mathematical work, he has actively taken part in social life which has resulted in 30 books, more than 300 articles, notes and interviews in books, newspapers and other sources. In this paper we present some of ideas of his mathematical work which have a great impact on further investigations.
\end{abstract}

Mathematics subject classification (2010): 26D15, 26D20, 41A10, 47A63, 65D32.

Keywords and phrases: convex function, harmonic polynomials, the Jensen inequality, the MondPečarić method, positive linear functional, quadrature formulae, the Steffensen inequality.

\section{REFERENCES}

[1] A. Aglić Aljinović, A. ČIVluak, S. Kovač, J. PeČARIĆ, M. Ribičić Penava, General integral identities and related inequalities, Element, Zagreb, 2013.

[2] A. Aglić AlJinović, J. PeČARIĆ, Error estimates for approximations of the Fourier transform of functions in $L_{p}$ spaces, Aust. J. Math. Anal. Appl. 1, 2 (2004), Article 10.

[3] A. Aglić Aljinović, J. PeČArić, A. Perušić, Generalizations of Steffensen's inequality via weighted Montgomery identity, Math. Inequal. Appl., 17 (2014), 779-799.

[4] P. R. BeESACK, J. PeČARIĆ, On Jessen's inequality for convex functions, J. Math. Anal. Appl. 110 (1985), 536-552.

[5] P. Bullen, A look at the work of Josip Pečarić, Math. Inequal. Appl., 12 (2014), 693-692.

[6] S. S. Dragomir, J. PeČArić, Refinements of some inequalities for isotonic functionals, Rev. Anal. Numer. Theor. Approx. 18 (1989) 61-65.

[7] I. FranjiĆ, J. PEČARIĆ, I. PeRIĆ, A. Vukelić, Euler integral identity, quadrature formulae and error estimations, Element, Zagreb, 2011.

[8] T. Furuta, J. Mićić Hot, J. PeČArić, Y. Seo, Mond-Pečarić Method in Operator Inequalities, Element, Zagreb, 2005.

[9] C. F. Gauss, Theoria combinationis observationum, 1821., German transl. in Abhandlungen zur Methode der kleinsten Quadrate. Neudruck. Würzburg 1964, pp. 9 and 12.

[10] M. MATIĆ, J. PEČARIĆ, N. UjEviĆ, Improvement and further generalization of some inequalities of Ostrowski-Grüss type, Comput. Math. Appl. 39 (2000), 161-175.

[11] G. V. Milovanović, J. PeČARIć, On generalizations of the inequality of A. Ostrowski and some related applications, Univ. Beograd Publ. Elektrotehn. Fak., Ser.Mat.Fiz., 544-576 (1976), 155-158.

[12] G. Milovanović, J. PeČarić, The Steffensen inequality for convex function of order $n$, Univ. Beograd Publ. Elektrotehn. Fak. Ser. Mat. Fiz. 634-677 (1979), 97-100.

[13] D. S. Mitrinović, J. PeČArić, A. M. Fink, Classical and new inequalities in analysis, Kluwer Acad. Publ. Dordrecht-Boston-London, 1993.

[14] D. S. Mitrinović, J. PeČarić, V. Volenec, Recent Advances in Geometric Inequalities, Kluwer Acad. Publ. Dordrecht-Boston-London, 1989.

[15] B. Mond, J. PeČARIĆ, Bounds for Jensen's inequality for several operators, Houston J. Math., 20 (1994), 645-651. 
[16] A. Ostrows KI, Aufgabensammlung zur Infinitesimalrechnung, Erster Band: Funktionen einer Variablen, Birkhäuser Verlag, Basel-Stuttgart, 1964.

[17] J. PeČARIĆ, On the Jensen-Steffensen inequality, Univ. Beograd Publ. Elektrotehn. Fak. Ser. Mat. Fiz. 634-677 (1979), 101-107.

[18] J. E. PeČARIĆ, On the Čebyšev inequality, Bul. Stiint. Tehn. Inst. Politehn. Timisoara 25(39) (1980), $10-11$.

[19] J. PeČARIĆ, A new proof of the Jensen-Steffensen inequality, Mathematica (Cluj) 23 (46) (1981), $73-77$.

[20] J. PEČARIĆ, Inverse of Jensen-Steffensen inequality, Glasnik Matematički 16 (36) (1981), 229-233.

[21] J. E. PEČARIĆ, Inverse of Steffensen's inequality, Glasnik Matematički Ser. III 17(37) (1982), 265270.

[22] J. PEČARIĆ, A short proof of a variant of Jensen's inequality, J. Math. Anal. Appl. 87 (1982), 278280.

[23] J. PeČARIĆ, An inequality for 3-convex function, J. Math. Anal. Appl. 90 (1982), 213-218.

[24] J. PeČARIĆ, On variants of Jessen's inequality, Glasnik Matematički 18 (38) (1983), 281-289.

[25] J. PEČARIĆ, A simple proof of the Jensen-Steffensen inequality, Amer. Math. Monthly 91 (1984), 195-196.

[26] J. E. PeČARIĆ, On the Bellman generalization of Steffensen's inequality II, J. Math. Anal. Appl. 104(2) (1984), 432-434.

[27] J. PEČARIĆ, The inductive proof of the Jensen-Steffensen inequality, Anal. Univ. Timisoara 23 (1985), 33-34.

[28] J. PeČARIĆ, On the Popoviciu conversion of Jensen's inequality, Revue Anal. Numer. Theor. Approx. 16 (1987) 65-68.

[29] J. PeČARIĆ, Konveksne funkcije: nejednakosti, Naučna knjiga, Beograd, 1987.

[30] J. E. PEČARIĆ, Connections among some inequalities of Gauss, Steffensen and Ostrowski, Southeast Asian Bull. Math. 13, 2 (1989), 89-91.

[31] J. PeČARIĆ, P. R. BEes ACK, On Jessen's inequality for convex functions II, J. Math. Anal. Appl. 118 (1986), 125-144.

[32] J. PeČArić, P. R. Beesack, Some Jessen-Beckenbach Inequalities, Rocky Mountain J. Math. 17 (1987), 629-641.

[33] J. E. PeČarić, P. R. Beesack, On Knopp's inequality for convex functions, Canad. Math. Bull. 30(3) (1987), 267-272.

[34] J. E. PeČArić, F. Proschan, Y. L. Tong, Convex functions, partial orderings and statistical applications, Mathematics in Science and Engineering, 187, Academic Press Inc., Boston, 1992.

[35] J. PeČarić, K. Smoljak Kalamir, S. VarošAnec, Steffensen's and related inequalities, Element, Zagreb, 2014.

[36] J. PeČArić, S. VArošanec, Multidimensional and discrete Steffensen inequality, Southeast Asian Bull. Math. 23(2) (1999), 277-284.

[37] J. PeČARIĆ, S. VAROŠANEC, Harmonic polynomials and generalization of Ostrowski inequality with applications in numerical integration, Nonlinear Analysis 47 (2001), 2365-2374.

[38] J. PEČARIĆ, S. VARoŠANEC, A note on Simpson's inequality for Lipschitzian functions, Soochow J. Math. 27 (2001), 53-57.

[39] J. PeČARIĆ, S. VARošAnec, On Simpson's formula for functions whose derivatives belong to $L_{p}$ spaces, Math. Appl. Letters 14 (2001), 131-135.

[40] J. F. STEFFENSEN, On certain inequalities between mean values and their application to actuarial problems, Skand. Aktuarietids. (1918), 82-97.

[41] P. M. VAsić, J. PeČArić, On the Jensen inequality, Univ. Beograd Publ. Elektrotehn. Fak. Ser. Mat. Fiz. 634-677 (1979), 50-54.

[42] P. M. VAsić, J. PeČARIĆ, Note on the Steffensen inequality, Univ. Beograd. Publ. Elektrotehn. Fak. Ser. Mat. Fiz. 716-734 (1981), 80-82. 